\title{
Quantification of Autoantibodies to Annexin V in Plasma by an "In House" Sandwich ELISA
}

\author{
Héctor F. Pelusa, ${ }^{*, a}$ María de los Ángeles Valdés, ${ }^{a}$ Stella M. Daniele, ${ }^{a}$ Adriana M. Almará, ${ }^{a}$ \\ María J. Svetaz, ${ }^{b}$ Mariela Bearzotti, ${ }^{b}$ Cecilia V. Paparella, ${ }^{c}$ Beatriz R. Bouvet, ${ }^{c}$ \\ Sergio A. Ghersevich ${ }^{a}$ and Sandra M. Arriaga ${ }^{a}$ \\ ${ }^{a}$ Área Bioquímica Clínica, Facultad de Ciencias Bioquímicas y Farmacéuticas, \\ Universidad Nacional de Rosario, Suipacha 531, S2002LRK, Rosario, Argentina \\ ${ }^{b}$ Sección Inmunidad Celular, Departamento Bioquímica Clínica, Facultad de Ciencias Bioquímicas y \\ Farmacéuticas, Universidad Nacional de Rosario, Suipacha 531, S2002LRK, Rosario, Argentina
cÁrea Química Analítica Clínica, Facultad de Ciencias Bioquímicas y Farmacéuticas, Universidad Nacional de Rosario, Suipacha 531, S2002LRK, Rosario, Argentina

Foi desenvolvido e validado um ELISA tipo sanduíche "in house" para a quantificação de anticorpos (Ac) anti-anexina $\mathrm{V}$ em plasma. Os parâmetros de validação estudados foram: (i) precisão, expressado como coeficiente de variação $(\mathrm{CV})$ inter- e intra-ensaio, (ii) exatidão, expressado como porcentagem de desvio entre o valor obtido e o valor real, (iii) limite de detecção (LOD), avaliado a partir do branco de reagentes e (iv) robusteza, obtida através da introdução propositada de pequenas variações em diferentes parâmetros. Além disso, a técnica "in house" foi comparada com um método comercial. Encontrou-se que ambos $\mathrm{CV}$ foram $<20 \%$, a exatidão foi de $100 \pm 20 \%$, o limite de detecção foi menor que $1 \mathrm{U} \mathrm{mL}^{-1} \mathrm{e}$ as pequenas variações na técnica não produziram variações significativas nos resultados. A comparação com o método comercial mostrou uma correlação aceitável. Concluiu-se que o método desenvolvido cumpre satisfatoriamente com os parâmetros de padronização e validação para imuno-análise.

An "in house" sandwich ELISA for the quantification of plasma anti-annexin V antibodies was developed and validated. The validation parameters studied were: $(i)$ precision, expressed either as the intra- or the inter-assay coefficient of variation (CV), (ii) exactitude, expressed as the percentage deviation between the obtained value and the real value, (iii) limit of detection (LOD), evaluated from the reagents blank and (iv) robustness, obtained by deliberately introducing slight variations in different parameters. Also, a comparison between the "in house" technique and a commercial method was performed. The research revealed that both $\mathrm{CV}$ were $<20 \%$, exactitude was within the $100 \pm 20 \%$ range, limit of detection was below $1 \mathrm{U} \mathrm{mL}^{-1}$ and that slight variations in the technique did not produce any significant variations in the results. Comparison with the commercial method showed an acceptable correlation. It was concluded that the method developed here satisfactorily accomplishes the parameters of standardization and validation for an immunoassay.

Keywords: ELISA, annexin V, antibodies, anti-phospholipid syndrome, foetal losses

\section{Introduction}

Annexins belong to a family of proteins that are able to bind to negatively charged phospholipids and membrane bilayers through calcium dependent interactions. Though their fine structure has been well described, their functions have not been clearly identified yet. ${ }^{1}$ Like others, annexins

\footnotetext{
*e-mail: fpelusa@ fbioyf.unr.edu.ar
}

constitute a group of ubiquitous cytoplasmic proteins involved in signal transduction. ${ }^{2}$

Annexin V is a 320-amino acid-residue, 36-kDa-protein that is folded into a planar cyclic arrangement of four repeats with each repeat composed of five alpha-helical segments. ${ }^{3,4}$ It is expressed in various cell types, including placental trophoblasts and vascular endothelial cells. This protein is highly expressed in an apparently constitutive manner by placental trophoblasts and is displayed 
on the apical membrane of the trophoblast cell line. ${ }^{5}$ Moreover, annexin $\mathrm{V}$ has been shown to be required for the maintenance of placental integrity in mice. Infusion of anti-annexin $\mathrm{V}$ IgG antibodies ( $\mathrm{Ab}$ ) into pregnant animals decreased annexin $\mathrm{V}$ availability to bind to the trophoblast surface and caused placental thrombosis, necrosis and foetal loss. ${ }^{6}$ There is also evidence that this protein plays a role in the maintenance of placental function in humans. Annexin $\mathrm{V}$ polymorphisms have been implicated as a risk factor for pregnancy losses. ${ }^{7,8}$ Reduction of annexin $\mathrm{V}$ in preeclampsia was associated with intrauterine growth restriction and with elevations of plasma level of fibrin degradation products and thrombin-antithrombin III complexes. ${ }^{9} 10$ These data support the concept that this protein may have a thrombomodulatory function at the maternal-foetal interface within the placental blood circulation by shielding apical membrane phospholipids from the critical phospholipid-dependent enzymatic reactions leading to blood clotting.

Anti-annexin V Ab were initially detected in patients with systemic lupus erythematosus (SLE).$^{11}$ These Ab have been associated with thrombotic events and/or recurrent abortions in patients with SLE and antiphospholipid syndrome (APLS), an autoimmune condition in which venous or arterial thrombosis and recurrent pregnancy losses occur in patients having serologic evidence of $\mathrm{Ab}$ against anionic phospholipid-protein complexes. Although the mechanisms leading to the occurrence of anti-annexin $\mathrm{V}$ Ab have not been completely elucidated yet, ${ }^{12}$ it has been proposed that, in the context of increased apoptosis, extracellular/membrane annexin $\mathrm{V}$ might constitute an antigenic stimulus for specific $\mathrm{Ab}$ production. Moreover, it is suspected that anti-annexin $\mathrm{V}$ $\mathrm{Ab}$ may interfere with annexin $\mathrm{V}$ functions and exerts a detrimental role leading to thrombosis and/or vascular occlusion. ${ }^{13}$ Nevertheless, there has been conflicting evidence regarding the correlation of $\mathrm{Ab}$ against annexin $\mathrm{V}$ with disease, with some studies indicating an association with clinical manifestations such as increased risk of pregnancy losses or thrombosis ${ }^{14-19}$ whereas others have found this not to be the case. ${ }^{20-22}$

The scarce information available and the controversy in the literature prompted us to design and implement an "in house" sandwich enzyme-linked immunosorbent assay to quantify plasma levels of anti-annexin $\mathrm{V} \mathrm{Ab}$, thus providing for the first time a standarized method only commercially available at present. This assay will allow us to clarify whether these $\mathrm{Ab}$ constitute a risk factor for thromboembolism and for miscarriages in a rapid, simple way of processing a large number of samples.

\section{Experimental}

Obtaining of "in house" calibrators

Different-titer anti-annexin $V$ plasma samples collected from SLE and APLS patients (negative for hepatitis B surface antigen and human immunodeficiency virus by U. S. Food and Drug Administration-approved methods) were identified using a commercially available ELISA kit for quantification of plasma levels of annexin $\mathrm{V} \mathrm{Ab}$ (Orgentec Diagnostika GmbH, Mainz, Germany). These samples were used as calibrators. The volume of $3 \mathrm{~mL}$ of venous blood was collected from every subject under complete aseptic conditions and added to EDTA-containing tubes $(1: 80)$. The tubes were gently rocked several times immediately after collection of blood to avoid clotting. Plasma was separated by centrifugation of the tubes at $3000 \mathrm{rpm}$ for $10 \mathrm{~min}$ and stored frozen at $-70{ }^{\circ} \mathrm{C}$ until examination of anti-annexin $\mathrm{V} \mathrm{Ab}$. Plasma is preferred to serum for the determination of these $\mathrm{Ab}$ to avoid inhibition of the immunological reaction by annexin $\mathrm{V}$ released from blood cells during clotting. ${ }^{23}$ Thus, samples showing slight hemolysis were readily discarded. No interference has been observed with lipemic or icteric plasma. The patients need not to be fasting, and no special preparations are necessary.

This study has been approved by the Bioethics Committee of our institution and patients have signed an informed consent.

\section{Controls}

All assays were validated by the inclusion of a positive and a negative control, as internal quality controls. Low-, medium- and high-titer positive controls were prepared by using pooled plasma obtained as described in section 1. Aliquots of $100 \mu \mathrm{L}$ were saved in eppendorf tubes and stored at $-70^{\circ} \mathrm{C}$. Samples collected from healthy individuals were used as negative controls. The concentration of anti-annexin $\mathrm{V} \mathrm{Ab}$ in these samples was below $6 \mathrm{U} \mathrm{mL}^{-1}$, the inferior limit of normality suggested by the commercial method. The Ab concentrations in the pooled plasma used as control were determined using the commercial kit mentioned in the former section and the values obtained with our "in house" method were considered as acceptable when they did not differ by more than $20 \% .^{24,25}$

"In-house" sandwich ELISA for detection of Ab to annexin V

The procedure is based on the sandwich principle of heterogeneous ELISA for detection of $\mathrm{Ab}$, where the 
antigen is immobilized on the solid phase, the sample contains the $\mathrm{Ab}$ to be determined, and the whole system is developed by means of a second Ab enzymatically labeled and directed to the first one.

Standarization of the technique was based on both the international literature available ${ }^{26-28}$ and our own previous experience. ${ }^{29}$ Plates were coated with different amounts $(5,7.5$ or $10 \mu \mathrm{g}$ per well) of native annexin $\mathrm{V}$ isolated from human placenta, (purity by sodium dodecyl sulfate electrophoresis: 93\%, Sigma Chemical Co.; St. Louis, MO, USA) and incubated at $4{ }^{\circ} \mathrm{C}$. No significant difference was found among the different amounts of antigen $(p>0.05)$, so the lowest one (5 $\mu \mathrm{g}$ per well) was chosen in order to optimize resources (data not shown).

Microwell strips (Nunc, Copenhagen, Denmark) were coated with annexin V $(5 \mu \mathrm{g}$ per well, used as capture antigen) diluted in carbonate-bicarbonate buffer pH 9.6 (Sigma Chemical Co., St. Louis, MO, USA) and incubated overnight at $4{ }^{\circ} \mathrm{C}$. Wells were then washed five times with phosphate buffer saline (PBS, $10 \mathrm{mmol} \mathrm{L}^{-1}$ sodium phosphate, $2.7 \mathrm{mmol} \mathrm{L}^{-1}$ potassium chloride and $137 \mathrm{mmol} \mathrm{L}^{-1}$ sodium chloride, $\mathrm{pH}$ 7.4) containing $0.05 \%$ Tween 20 (PBS-T) and blocked with $100 \mu \mathrm{L}$ of $1 \% \mathrm{~m} / \mathrm{v}$ bovine serum albumin (BSA, Sigma Chemical Co., St Louis, MO, USA) in PBS for $60 \mathrm{~min}$ at room temperature. After three washes with PBS-T, $100 \mu \mathrm{L}$ of calibrators and positive and negative controls (diluted 1:100 in PBS-BSA) were added to each well. After $60 \mathrm{~min}$ of incubation at room temperature, wells were washed four times with PBS-T. The amount of $50 \mu \mathrm{L}$ of peroxidase-conjugated goat $\mathrm{Ab}$ to either human IgG or IgM (Sigma Chemical Co., St Louis, MO, USA) diluted in PBS-BSA (1:15000 and 1:30000, respectively) were added to each well and incubated for $30 \mathrm{~min}$ at room temperature. After four short washes and one five-min-wash with PBS-T, $50 \mu \mathrm{L}$ of chromogenic substrate (3,3',5,5'-tetramethylbenzidine, TMB, Sigma Chemical Co., St Louis, MO, USA) were added to each well and allowed to develop for $15 \mathrm{~min}$. The reaction was stopped by addition of $50 \mu \mathrm{L}$ of $1 \mathrm{~mol} \mathrm{~L}^{-1} \mathrm{HCl}$ and optical densities were recorded at $450 \mathrm{~nm}$ by means of a Sirio S ELISA microplate reader (Radim, Italy), using a $630 \mathrm{~nm}$ filter as a reference. A calibration curve was performed by plotting optical density $v s$. calibrators concentrations $\left(5,15,30,40\right.$ and $\left.80 \mathrm{U} \mathrm{mL}^{-1}\right)$ on a semi logarithmic scale (Figure 1).

\section{Validation parameters}

\section{Precision}

Precision is the concordance rate among the values obtained in a measurement system and it is expressed as the

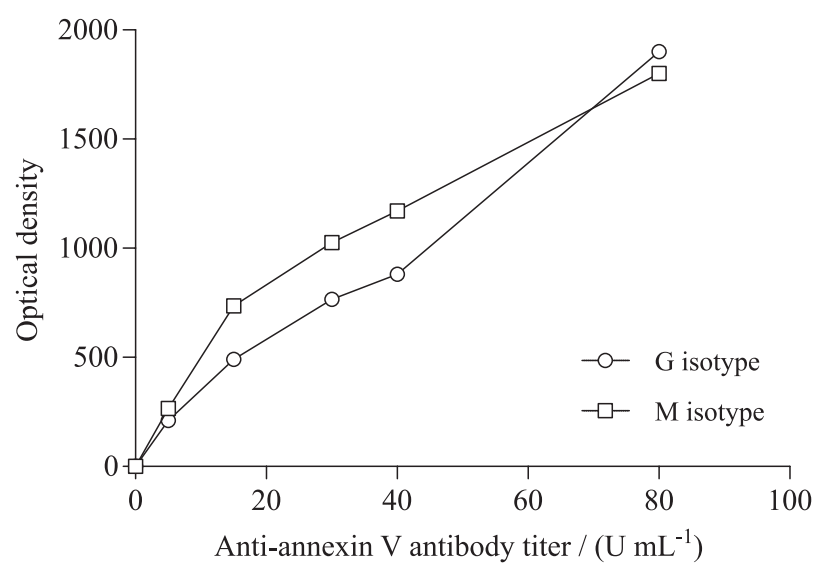

Figure 1. Calibration curves for $\operatorname{IgG}$ and $\operatorname{IgM}$ isotypes were obtained by plotting optical density $v s$. concentration of the calibrators used $(5,15$, 30,40 and $80 \mathrm{U} \mathrm{mL}^{-1}$ ) in a semilogarithmic scale. Each point represents mean of four repeats.

coefficient of variation (CV). The $\mathrm{CV}$ is the ratio between the standard deviation (SD) of the values obtained from the assays and the mean concentration of the analyte (\%). Different types of precisions can be determined: (i) the intra-assay precision (or repeatability) is the $\mathrm{CV}$ of multiple determinations of only one sample processed in a unique series of assays; (ii) the inter-assay precision (also known as intermediate precision) is expressed as the $\mathrm{CV}$ of multiple determinations of only one sample, controls and reagents processed in various series of assays performed in the same laboratory; and (iii) the reproducibility, that is the precision among different laboratories, is worth determining in collaborative studies, but it has no meaning in the validation of assays within the same laboratory. In the present study, precision was estimated by titrating three plasma samples of high, medium and low titers of IgG and $\mathrm{IgM}$ anti-annexin $\mathrm{V} \mathrm{Ab}$. Four replicates were carried out for intra- and inter-assay studies. CV was calculated and a value below $20 \%$ was considered acceptable. ${ }^{24,25}$

\section{Exactitude}

Exactitude is the concordance rate between the real value and the measured value for the assayed parameter. It is expressed as the percentage deviation or the percentage error between the observed value and the real value (experimental value/real value) $\times 100 \% .^{24,25}$

In this study, a sample of known titer of anti-annexin $\mathrm{V}$ $\mathrm{IgG}$ or $\mathrm{IgM}$ was assayed sevenfold in the same plate and a percentage deviation of $100 \pm 20 \%$ was considered acceptable. $^{30}$

\section{Limit of detection}

The limit of detection (LOD) is the lowest amount of the analyte that can be detected but not necessarily quantified 
as an exact concentration or amount. For the evaluation of this parameter, four repeats of the reagents blank were performed in three different plates for each isotype of anti-annexin V Ab evaluated in this study. The LOD was calculated by adding three times the standard deviation to the mean value. ${ }^{31}$

\section{Robustness}

Robustness is the ability of a test not to be affected by slight modifications deliberately introduced in different parameters and constitutes an indication of the reliability of the method in normal conditions. Such variations can be introduced either in the temperature or humidity of the incubation room or incubation chamber, in the incubation periods of time or in the $\mathrm{pH}$ value of a reagent (inside a narrow range), among others. The exactitude and precision or any other valuation parameter must be assessed for each condition in order to determine which modifications are well tolerated under assay conditions. ${ }^{25}$ Slight variations were introduced in the currently developed technique with the aim of determining their influence on the final results. Variations in BSA concentration used in the blocking solution $(1,2$ or $3 \%$ ), blocking periods of time ( 60 or $90 \mathrm{~min}$ ), temperature applied to the blocking process (room temperature or $37^{\circ} \mathrm{C}$ ) and periods of time for the recording of final color optical density $(5,15,30$ or $45 \mathrm{~min})$ were performed. Also, it was tested the reproducibility of the assay of different plate lots (1 and 2) and antigen lots (1 and 2) from the same commercial supplier. These variations were carried out for each $\mathrm{Ab}$ isotype. Besides, results obtained using a polyclonal peroxidase-conjugated rabbit Ab to either human IgG or IgM (DakoCytomation, Glostrup, Denmark) diluted in PBS-BSA (1:6000 and 1:1000, respectively) were also analyzed.

Comparison between the "in house" method and the commercial kit

The "in house" ELISA was compared to one of the two kits available in our country, provided by Orgentec
Diagnostika GmbH, Mainz, Germany. Sixty-eight plasma samples, 38 from non-pregnant, childbearing age healthy women and 30 from SLE and APLS women patients, were analyzed through both techniques, as well as low, medium and high titer positive controls. This comparison was carried out for each $\mathrm{Ab}$ isotype.

\section{Statistical analysis}

Statistical analysis was performed by using one-way analysis of variance followed by the Bonferroni's multiple range test, student's $t$ test and Friedman test. Values of $p<0.05$ were considered to be statistically significant.

\section{Results and Discussion}

In this study, a diagnostic Ab-detection ELISA for anti-annexin $\mathrm{V} \mathrm{Ab}$ was developed and evaluated and the optimal conditions for the determination of this Ab were established.

\section{Validation of the ELISA}

\section{Precision}

The CV values obtained in the intra-assay precision study of three plasma samples were lower than $20 \%$ (Table 1) for each Ab isotype. These results are below the limit accepted by the World Health Organization (WHO) for such techniques. ${ }^{24,25}$ The same happened to the $\mathrm{CV}$ values obtained in the inter-assay study (Table 2).

These results are considered satisfactory for immunoassays as reported by Laureen et al. ${ }^{32}$ It has to be born in mind that precision is limited by both accidental and technical, manual errors that cannot always be avoided..$^{33}$ This lets us assume that the slight imprecision found here does not abolish the reproducibility of our results.

\section{Exactitude}

A sample of known titer was assayed sevenfold in the same plate and exactitude results are shown in Table 3.

Table 1. Coefficient of variation $(\mathrm{CV})$ in the repeatability assay

\begin{tabular}{|c|c|c|c|c|}
\hline \multirow{3}{*}{ Sample } & \multicolumn{4}{|c|}{ Anti-annexin V antibody } \\
\hline & \multicolumn{2}{|l|}{$\operatorname{IgG}$} & \multicolumn{2}{|l|}{$\operatorname{IgM}$} \\
\hline & Mean concentration / $\left(\mathrm{U} \mathrm{mL}^{-1}\right)$ & $\mathrm{CV} / \%$ & Mean concentration / $\left(\mathrm{U} \mathrm{mL}^{-1}\right)$ & $\mathrm{CV} / \%$ \\
\hline High titer & 44 & 15 & 38 & 16 \\
\hline Medium titer & 16 & 8 & 18 & 11 \\
\hline Low titer & 8 & 9 & 8 & 13 \\
\hline
\end{tabular}

The intra-assay precision (or repeatability) was estimated by titrating three plasma samples of high, medium and low titers of IgG and IgM anti-annexin $\mathrm{V}$ antibody processed in a unique series of assays. Each value represents the mean of four experiments. 
Table 2. Coefficient of variation (CV) in the intermediate precision assay

\begin{tabular}{|c|c|c|c|c|}
\hline \multirow{3}{*}{ Sample } & \multicolumn{4}{|c|}{ Anti-annexin V antibody } \\
\hline & \multicolumn{2}{|l|}{$\operatorname{IgG}$} & \multicolumn{2}{|c|}{$\operatorname{IgM}$} \\
\hline & Mean concentration / $\left(\mathrm{U} \mathrm{mL}^{-1}\right)$ & $\mathrm{CV} / \%$ & Mean concentration / $\left(\mathrm{U} \mathrm{mL}^{-1}\right)$ & $\mathrm{CV} / \%$ \\
\hline High titer & 42 & 14 & 40 & 15 \\
\hline Medium titer & 15 & 13 & 16 & 13 \\
\hline Low titer & 8 & 12 & 7 & 16 \\
\hline
\end{tabular}

The inter-assay precision (or intermediate precision) was estimated by titrating three plasma samples of high, medium and low titers of IgG and $\mathrm{IgM}$ anti-annexin $\mathrm{V}$ antibody processed in various series of assays performed in the same laboratory. Each value represents the mean of four experiments.

Table 3. Percentage deviation in the exactitude assay

\begin{tabular}{lccccc}
\hline $\begin{array}{l}\text { Anti-annexin V } \\
\text { antibody isotype }\end{array}$ & $\begin{array}{c}\text { Real value / } \\
\left(\mathrm{U} \mathrm{mL}^{-1}\right)\end{array}$ & $\begin{array}{c}\text { Mean measured value / } \\
\left(\mathrm{U} \mathrm{mL}^{-1}\right)\end{array}$ & $\mathrm{SD}$ & $\mathrm{CV} / \%$ & $\begin{array}{c}\text { Percentage } \\
\text { deviation / \% }\end{array}$ \\
\hline IgG & 47.0 & 43.29 & 5.21 & 12 & 92 \\
IgM & 40.0 & 39.07 & 5.02 & 13 & 98 \\
\hline
\end{tabular}

The exactitude of the assay was estimated by titrating a sample of known titer for IgG and IgM anti-annexin V antibody in the same plate. Each value represents the mean of seven experiments; SD: standard deviation; CV: coefficient of variation.

Percentage deviation was inside the established interval $(100 \pm 20 \%)^{30}$ for both isotypes of $\mathrm{Ab}$. Considering that the exactitude depends on the immunoenzymatic reaction, the sample studied and the specificity of the method, it can be assumed that the current strategy of development of our "in house" assay was adequate.

\section{Limit of detection}

The LODs obtained for our assay were 0.6 and $0.8 \mathrm{U} \mathrm{mL}^{-1}$ for IgG and IgM isotypes, respectively (Table 4). This indicates that our assay would be capable of detecting minimum quantities of anti-annexin $\mathrm{V} \mathrm{Ab}$. It is worth noting that the coating process of the solid phase is essential to obtain good results for this parameter. ${ }^{34}$

\section{Robustness}

Different concentrations of BSA in the blocking solution (Figure 2a), different incubation temperatures (Figure 2b) and different incubation periods (Figure 2c) were tested. Neither variations in the concentrations of BSA $(p>0.05)$ nor variations in the duration and temperature of the blocking period $(p>0.05)$ produced any significant changes. Final color intensity was assessed by recording absorbance at $450 \mathrm{~nm}$ using a reference filter $(630 \mathrm{~nm})$, at different periods of time (Figure 2d). No significant difference was obtained among the periods of time evaluated $(p>0.05)$ either for IgG and IgM anti-annexin V Ab.

When analyzing the effect of different plate lots (Figure 3a) and antigen lots (Figure 3b), no statistically significant difference was found $(p>0.05)$. Using another conjugate (Figure $3 \mathrm{c}$ ) did not produce any significant change in the results either $(p>0.05)$.

Taken together, these results suggest that slight variations in the ELISA technique developed do not produce any significant variations in the assessment of Ab titers.

\section{Comparison between the "in house" method and the} commercial kit

Figures $4 \mathrm{a}$ and $4 \mathrm{~b}$ shows the results obtained with individual plasma samples in both ELISA techniques in which an acceptable correlation can be seen $(r=0.94$ and $\mathrm{r}=0.93$ for $\mathrm{G}$ and $\mathrm{M}$ isotypes, respectively; $p<0.05$ ).

Table 4. Limit of detection for the immunoassay

\begin{tabular}{lcccc}
\hline $\begin{array}{l}\text { Anti-annexin } \mathrm{V} \\
\text { antibody isotype }\end{array}$ & $\begin{array}{c}\text { Mean optical density for } \\
\text { the reagents blank }\end{array}$ & SD & $\begin{array}{c}\text { Limit of detection } \\
\text { (OD measurement) }\end{array}$ & $\begin{array}{c}\text { Limit of detection / } \\
\left(\mathrm{U} \mathrm{mL} \mathrm{m}^{-1}\right)\end{array}$ \\
\hline $\mathrm{IgG}$ & 31 & 9 & 58 & 0.6 \\
$\mathrm{IgM}$ & 26 & 9 & 53 & 0.8 \\
\hline
\end{tabular}

The limit of detection was determined by four repeats of the reagents blank in three different plates for each isotype of the anti-annexin V antibody. Each value represents the mean of three series of experiments. OD: optical density. 
(a)

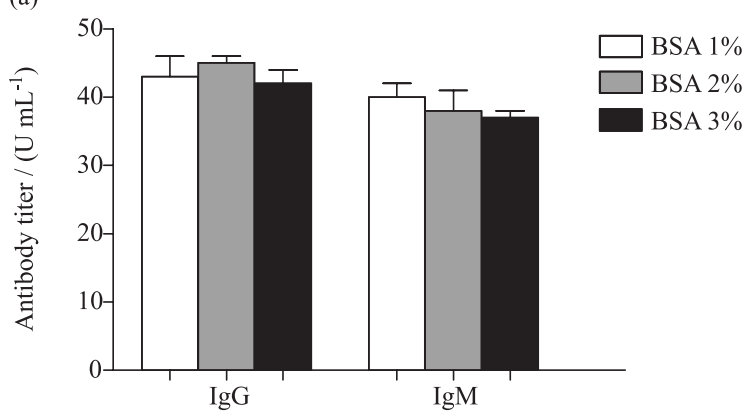

(c)

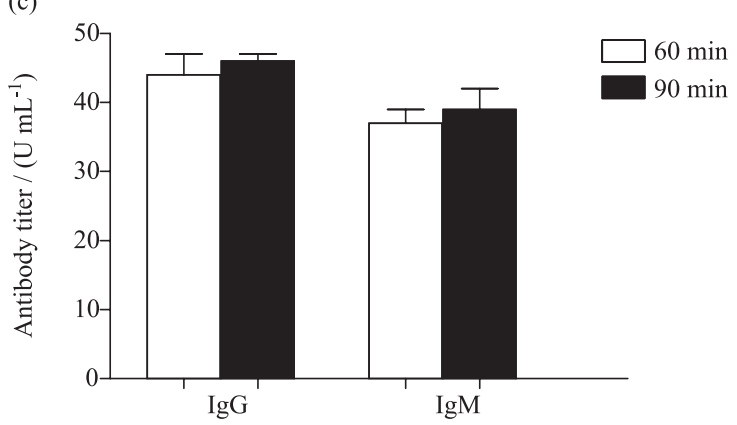

(b)

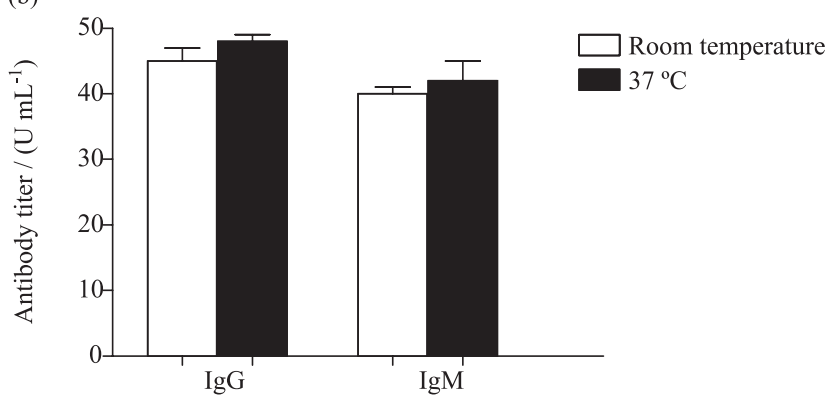

(d)

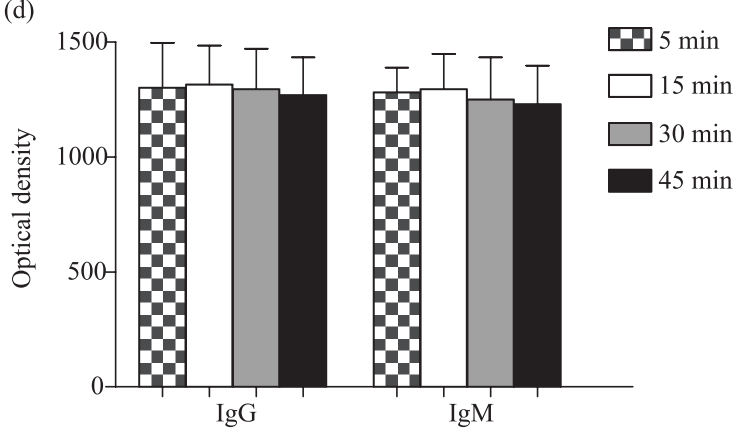

Figure 2. (a) Variations in the concentration of BSA in the blocking solution. IgG and IgM anti-annexin V Ab titers were determined using 1,2 or $3 \%$ BSA in the blocking solution. No significant difference was found among the different concentrations either for $\operatorname{IgG}$ and $\operatorname{IgM}(p>0.05)$. Each value represents the mean $\pm \mathrm{SD}(\mathrm{n}=3)$. (b) Variations in the temperature of the blocking period. IgG and IgM anti-annexin $\mathrm{V}$ Ab titers were determined after blocking either at room temperature or $37^{\circ} \mathrm{C}$. No significant difference was observed between the temperatures tested for both isotypes $(p>0.05)$. Each value represents the mean $\pm \mathrm{SD}(\mathrm{n}=3)$. (c) Variations in the duration of the blocking period. IgG and IgM anti-annexin $\mathrm{V}$ Ab titers were determined after blocking for 60 and $90 \mathrm{~min}$. No significant difference was found between the periods of time assayed for either isotype $(p>0.05)$. Each value represents the mean \pm SD $(n=3)$. (d) Variations in the final color recording time. Final color intensity was assessed by recording absorbance at $450 \mathrm{~nm}$ using a reference filter $(630 \mathrm{~nm})$ at 5, 15, 30 and $45 \mathrm{~min}$. No significant difference was obtained among the periods of time evaluated either for $\operatorname{IgG}$ and $\operatorname{IgM}(p>0.05)$. Each value represents the mean $\pm \operatorname{SD}(\mathrm{n}=3)$.
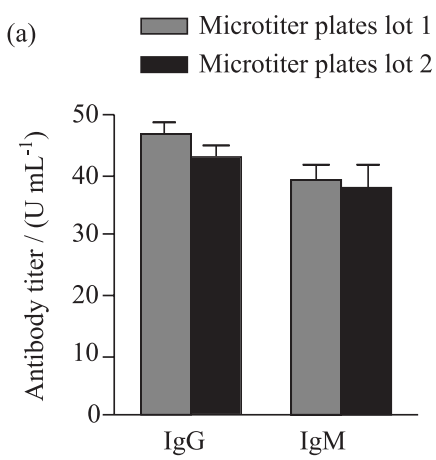

(b)
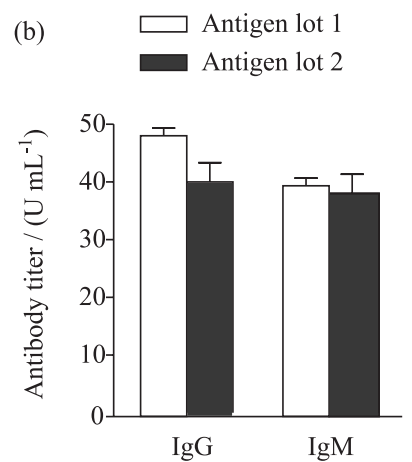

(c) $\square$ HRP conjugated goat $\mathrm{Ab}$

$\square$ HRP conjugated rabbit $\mathrm{Ab}$

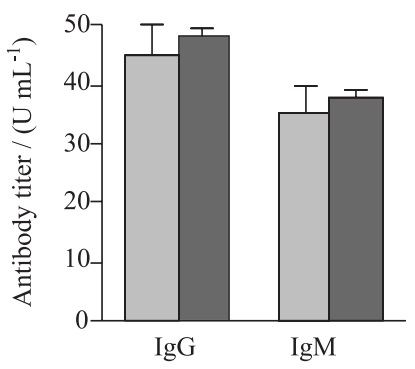

Figure 3. (a) Variation in plate lots. Both anti annexin V antibody isotypes were determined using different plate lots. No statistically significant difference was found between lots for both immunoglobulin isotypes $(p>0.05)$. (b) Variation in antigen lot. Both anti annexin V antibody isotypes were determined using different antigen lots. No statistically significant difference was found between lots for both immunoglobulin isotypes ( $p>0.05$ ). (c) Variation in the source and commercial supplier of the conjugate. Both anti annexin $\mathrm{V}$ antibody isotypes were determined using different conjugates, one developed in goat and the other in rabbit. No statistically significant difference was found between conjugates tested for both immunoglobulin isotypes $(p>0.05)$.

$\mathrm{CV}$ and LOD values obtained for both techniques are shown in Table 5. While no differences were observed in LOD values, intra- and inter-assay CV were higher for the "in house" technique than for the commercial method, nevertheless, values were within the acceptable range for validation. ${ }^{25}$ Performance of the "in house" ELISA was comparable to the commercial kit.

\section{Conclusions}

The laboratory methodology used for the detection of anti-annexin V Ab is crucial. Enzyme-linked immunoassays are currently the most commonly used methods because they are easily performed, potentially may be automated, and allow the screening of large numbers of samples. 
Table 5. Comparison between the "in house" method and the commercial kit

\begin{tabular}{lcccccc}
\hline \multirow{2}{*}{$\begin{array}{l}\text { Anti-annexin V } \\
\text { antibody isotype }\end{array}$} & \multicolumn{2}{c}{ Intra-assay CV / } & \multicolumn{2}{c}{ Inter-assay CV / \% } & \multicolumn{2}{c}{ Limit of detection / (U mL $\left.{ }^{-1}\right)$} \\
\cline { 2 - 7 } IgG & "In house" EIA & Commercial EIA & "In house" EIA & Commercial EIA & "In house" EIA & Commercial EIA \\
\hline $\mathrm{IgM}$ & 11 & $3.8-6.7$ & 13 & $4.1-5.7$ & 1.0 & 0.6 \\
\hline
\end{tabular}

Validation parameters for the "in house" method were compared to those of the commercial kit provided by the supplier. No difference was observed for LOD values and, although intra- and inter-assay CV were higher for the "in house" technique, they were within the aceptable range for validation.
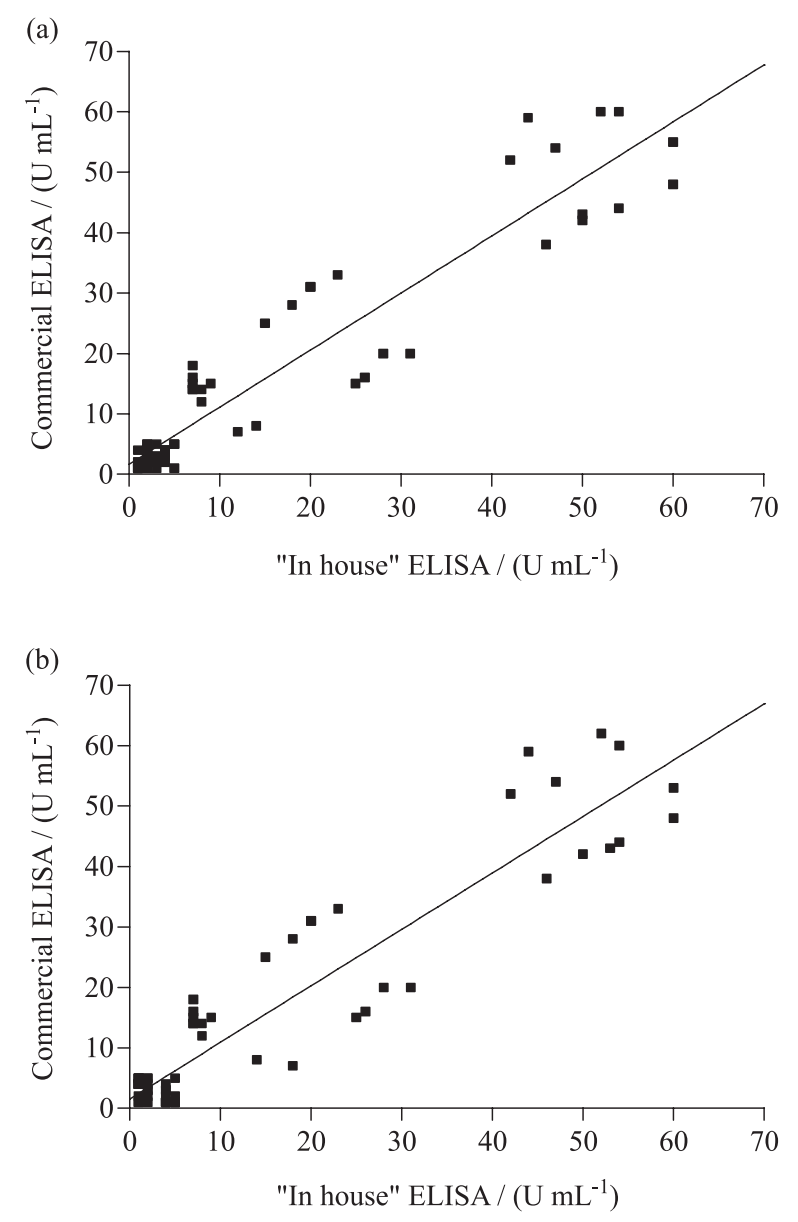

Figure 4. Correlation between "in house" ELISA and commercial ELISA in the determination of antibodies anti annexin V. Sixty-eight plasma samples were assayed by both techniques obtaining a correlation of 0.94 for IgG isotype [p $<0.05$; panel (a)] and of 0.93 for IgM isotype [p $<0.05$; panel (b)].

The method currently developed satisfactorily accomplishes the parameters of standardization and validation for an immunoassay. ${ }^{26-28}$ Therefore, it is possible to rely on an "in house" ELISA technique for the evaluation of the content of anti-annexin $\mathrm{V} \mathrm{Ab}$ in plasma with high reproducibility and reliability. Furthermore, because of its feasible execution, it can be recommended as a quantification assay for plasma levels of anti-annexin $\mathrm{V} \mathrm{Ab}$ in patients with SLE and APLS. On the other hand, due to controversy towards the clinical implications of these $\mathrm{Ab}$ in the pregnancy losses, it is believed that a useful tool for the investigation of populations suffering from recurrent abortion is being provided.

\section{Acknowledgements}

The authors would like to thank Dr. Aldo D. Mottino for his critical reading and helpful suggestions, and Dr. Cecilia L. Basiglio for language revision. This work was financially supported by the Universidad Nacional de Rosario (UNR), Argentina.

\section{References}

1. Benz, J.; Hofmann, A.; Biol. Chem. 1997, 378, 177.

2. Gerke, V.; Moss, S.; Physiol. Rev. 2002, 82, 331.

3. Grundmann, U.; Abel, K. J.; Bohn, H.; Löbermann, H.; Lottspeich, F.; Küpper, H.; Proc. Natl. Acad. Sci. U. S. A. 1988, 85,3708 .

4. Huber, R.; Berendes, R.; Burger, A.; Luecke, H.; Karshikov, A.; Behring Inst. Mitt. 1992, 91, 107.

5. Vogt, E.; Ng, A. K.; Rote, N. S.; Am. J. Obstet. Gynecol. 1997, $177,964$.

6. Wang, X.; Campos, B.; Kaetzel, M. A.; Dedman, J. R.; Am. J. Obstet. Gynecol. 1999, 180, 1008.

7. de Laat, B.; Derksen, R. H.; Mackie, I. J.; Roest, M.; Schoormans, S.; Woodhams, B. J.; de Groot, P. G.; van Heerde, W. L.; Ann. Rheum. Dis. 2006, 65, 1468.

8. Rand, J. H.; Wu, X. X.; Guller, S.; Gil, J.; Guha, A.; Scher, J.; Lockwood, C. J.; Am. J. Obstet. Gynecol. 1994, 171, 1566.

9. Shu, F.; Sugimura, M.; Kanayama, N.; Kobayashi, H.; Kobayashi, T.; Terao, T.; Gynecol. Obstet. Invest. 2000, 49, 17.

10. Bogdanova, N.; Horst, J.; Chlystun, M.; Croucher, P. J. P.; Nebel, A.; Bohring, A.; Todorova, A.; Schreiber, S.; Gerke, V.; Krawczak, M.; Markoff, A.; Hum. Mol. Genet. 2007, 16, 573.

11. Gajtan, E.; Tambya, M. C.; Chanseauda, Y.; Servettaza, A.; Guillevinb, L.; Mouthona, L.; Autoimmun. Rev. 2005, 4, 55.

12. Rand, J. H.; Curr. Rheumatol. Rep. 2000, 2, 246.

13. Nakamura,N.; Shidara,Y.; Kawaguchi,N.;Azuma, C.; Mitsuda,N.; Onishi, S.; Yamaji, K.; Wada, Y.; Biochem. Biophys. Res. Commun. 1994, 205, 1488. 
14. Kaburaki, J.; Kuwana, M.; Yamamoto, M.; Kawai, S.; Ikeda, Y.; Am. J. Hematol. 1997, 54, 209.

15. Satoh, A.; Suzuki, K.; Takayama, E.; Kojima, K.; Hidaka, T.; Kawakami, M.; Matsumoto, I.; Ohsuzu, F.; J. Rheumatol. 1999, 26, 1715.

16. Sugiura, K.; Muro, Y.; J. Rheumatol. 1999, 26, 2168.

17. Zammiti, W.; Mtiraoui, N.; Hidar, S.; Fekih, M.; Almawi, W. Y.; Mahjoub, T.; Arch. Gynecol. Obstet. 2006, 274, 261.

18. Zammiti, W.; Mtiraoui, N.; Kallel, C.; Mercier, E.; Almawi, W.Y.; Mahjoub, T.; Reproduction 2006, 131, 817.

19. Rand, J. H.; Arslan, A. A.; Wu, X. X.; Wein, R.; Mulholland, J.; Shah, M.; van Heerde, W. L.; Reutelingsperger, C. P.; Lockwood, C. J.; Kuczynski, E.; Am. J. Obstet. Gynecol. 2006, 194, 182.

20. Siaka, C.; Lambert, M.; Caron, C.; Amiral, J.; Hachulla, E.; Hatron, P. Y.; Goudemand, J.; Rev. Med. Interne 1999, $20,762$.

21. Ogawa, H.; Zhao, D.; Dlott, J. S.; Cameron, G. S.; Yamazaki, M.; Hata, T.; Triplett, D. A.; Am. J. Clin. Pathol. 2000, 114, 619.

22. Arai, T.; Matsubayashi, H.; Sugi, T.; Kondo, A.; Shida, M.; Suzuki, T.; Izumi, S. I.; McIntyre, J. A.; Makino, T.; Am. J. Reprod. Immunol. 2003, 50, 202.

23. Kuragaki, C.; Kidoguchi, K.; Nakamura, N.; Wada, Y.; Am. J. Hematol. 1995, 50, 68 .

24. Aboul-Enein, H. Y.; Emafo, P. O.; Gupta, P. K.; Layloff, T.; Lik, N.; Paal, T.; Rabouhans, M. L.; Zhong-Yuan, Y.; Comité de Expertos de la OMS en Especificaciones para las Preparaciones Farmacéuticas, Prácticas Adecuadas para la Fabricación de Productos Farmacéuticos, Ginebra, 1992, Serie de Informes Técnicos No. 823, Anexo 1. http://whqlibdoc.who.int/trs/ WHO_TRS_823_spa.pdf

25. Chaloner-Larsson, G.; Anderson, R.; Egan, A.; Guía de la OMS sobre los Requisitos de las Prácticas Adecuadas de Fabricación (PAF), Segunda parte: Validación (WHO/
VSQ/97.02), Ginebra, 1998, 70. http://whqlibdoc.who.int/ hq/1997/WHO_VSQ_97.02_spa.pdf

26. Betts Carpenter, A. In Manual of Clinical Laboratory Immunology, $6^{\text {th }}$ ed.; Rose, N.; de Macario, E.; Fahey, J.; Friedman, H.; Penn, G., eds.; America Society for Microbiology: Washington D. C., 1992, ch. 2.

27. Stenman, U. H. In Principles and Practices of Immunoassay, $2^{\text {nd }}$ ed.; Price, C. P.; Newman, D. J., eds.; Macmillan: London, 1997, ch. 11.

28. Tijsen, P. In Practice and Theory of Enzyme Immunoassay; Burdon, R. H.; Van Knippenberg, P. H., eds.; Processing Elsevier Sci. Pub. B. V.: Amsterdam, Netherlands, 1985, ch. 15.

29. Basiglio, C.; Arriaga, S.; Pelusa, H.; Almará, A.; Roma, M.; Mottino, A.; Biochem. Biophys. Acta 2007, 1770, 1003.

30. Fajardo, E.; Delgado, I.; Riverón, L.; Izquierdo, L.; Iglesias, N.; Álvarez, E.; Perojo, A.; Costa, N.; Tamayo, Y.; Jorge, E.; Hernández, B.; Díaz, Y.; Cruces, A.; Gutiérrez, N.; Puig, A.; Mandiarote, A.; Martínez, R.; Cardoso, D.; VacciMonitor. 2006, 15, 5 .

31. Broughton, P. M. G.; Bergonzi, C.; Lindstedt, G.; Loeber, I. G.; Malan, P. G.; Mathieu, M.; Pozet, S.; Guidelines for a User Laboratory to Evaluate and Select a Kit for its Own Use, in Part 1: Quantitative Tests; European Committee for Clinical Laboratory Standards: London 1986, 3.

32. Laureen, E. L.; BioPharmaceutical 1995, 36.

33. Sokoll, L. J.; Chan, D. W.; Anal. Chem. 1999, 71, 356.

34. Ochoa, R.; Martínez, J. C.; Estrada, E.; García, A. M.; Ferriol, X.; Blanco, R.; VacciMonitor. 2000, 9, 17.

Submitted: July 28, 2011

Published online: January 10, 2012 